\title{
THE ESTERASES OF MOUSE BLOOD*
}

\author{
Robert L. Hunter and Donald S. Strachan $\dagger$ \\ Department of Anatomy, Medical School, University of Michigan, Ann Arbor, Mich.
}

Three respects in which esterases tend to be unlike other enzymes are: they possess a low order of substrate specificity; they have been studied with a wide variety of biochemical techniques with less agreement of results than one would like; and, there are several esterases coexisting in each species, the exact number and function of each of which is still to be determined. If we are to study these esterases, techniques must be applied that will isolate the individual active protein in order that it may be characterized biochemically. The use of electrophoretic methods, by a number of investigators, ${ }^{1-7,11-18}$ followed by characterization of the isolated protein either on the electrophoretic column or extracted from the column, has furnished an important contribution to our understanding of this group of enzymes. The introduction of starch gel as a medium in which to carry out electrophoretic separations has effectively increased our capacity to resolve proteins. Using this technique combined with histochemical methods for dehydrogenases and esterases, Markert and Møller ${ }^{16}$ and Allen ${ }^{2}$ were able to demonstrate multiple proteins that showed common properties except for differing electrophoretic mobility; these were identified by them as isozymes. Stimulated by their observations we have proceeded to study the multiple esterases previously demonstrated ${ }^{13,15}$ to be present in mouse blood in order to determine whether similar isozymic groups could be identified in this material.

Throughout this report we shall refer repeatedly to the esterase-active proteins located in numbered bands on the starch-gel column, demonstrated by histochemical methods. Rather than characterize and qualify this each time we have adopted the convention of referring to "bands" when, in fact, the whole concept is intended.

\section{Materials and Methods}

The mice used in this study were an inbred strain, Palid, $\ddagger$ and Swiss albino. The two strains were used interchangeably since the zymogram prepared from the blood of one could not be distinguished from that prepared from the other.

Mice were anesthetized with ether, and blood was withdrawn from the left ventricle into a 21 gauge needle and a heparin $(1 \mathrm{mg} . / 5 \mathrm{ml}$. saline $)$ rinsed syringe. After centrifugation at $5000 \mathrm{~g}$ for $10 \mathrm{~min}$. the plasma was removed, the remaining red blood corpuscles (RBCs) were resuspended in $40 \mathrm{ml}$. of 0.9 per cent saline and the mixture was centrifuged. This last procedure was repeated 3 times. The RBC fraction was obtained then by discarding the supernatant. Previous studies showed no differences in zymograms prepared from serum or plasma.

The mechanics of the starch-gel electrophoresis procedure have been as pre-

* 'The work reported in this paper was supported in part by Grant G-6140 from the National Science Foundation, Washington, D. C.

† Postdoctoral trainee DT-13 (C 3), United States Public Health Service.

$\ddagger$ From the Jackson Memorial Laboratory, Bar Harbor, Me. 
viously reported. ${ }^{12,15}$ The gels were poured in the morning and allowed to cool for $90 \mathrm{~min}$. before using. Ten $\mu \mathrm{l}$. of freshly prepared samples were pipetted onto a 5- $\times 13-\mathrm{ml}$. piece of filter paper for insertion at the origin. After electrophoresis for 4 hours the sliced gels were placed in the substrate diazonium mixture for a period of exactly $30 \mathrm{~min}$. at $37^{\circ} \mathrm{C}$. The hydrolysis of naphthol AS acetate, indoxyl acetate, or the combination of sodium taurocholate with beta naphthyl laurate was slower; these gels were incubated for 1,12 , and 2 to 3 hours respectively.

In the inhibition studies the gels were placed in the inhibitor solution 10 min. prior to the addition of the substrate mixture. Thirty-min. incubation with the inhibitor did not alter the results but caused a slight fuzzy appearance of the bands from diffusion of the enzyme in the starch. An important consideration in the inhibition studies was that when the gels were washed after staining and allowed to remain in water, the bands previously inhibited reacted with the gel-absorbed substrate and dye and then appeared less inhibited.

Table 1

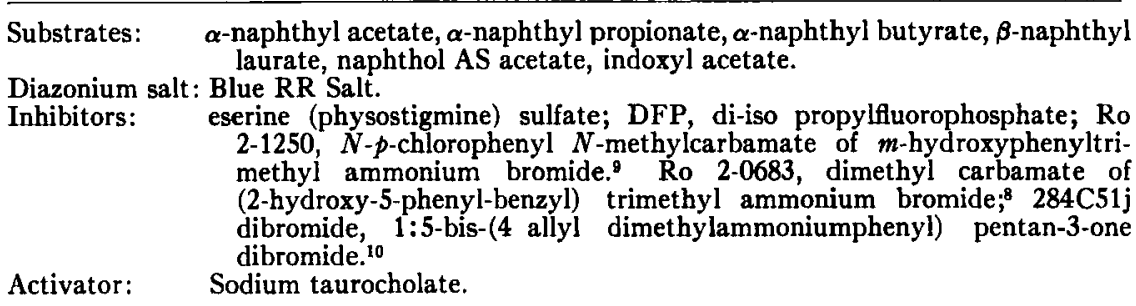

To meet this problem the inhibitor was added to the water and the gels were photographed immediately (TABLE 1).

Plasma samples from more than 200 mice were examined; the inhibitors were studied a minimum of four times at each concentration. The molar concentrations used are listed to the right of each inhibitor in the figure.

\section{Results}

Nine bands in plasma are demonstrated consistently. We have labeled the fastest moving band No. 1 and the slowest No. 9. Occasionally a faintlystaining band between bands 5 and 6 can be observed. Bands 5 and 7 are not as prominent as the others and therefore their interaction with inhibitors is more difficult to interpret. This seems to be related to the esterase activity present and to the spreading of these proteins in the electrophoretic field, resulting in a wide weak band. If the plasma sample is stored under refrigeration without freezing or is kept at room temperature for a few hours, the area of band 2 shows no esterolytic activity. Freezing retains this activity, but to avoid possible changes fresh samples were prepared each day.

All bands are demonstrated by $\alpha$-naphthyl acetate, butyrate and propionate except band 9, which is not distinct with $\alpha$-naphthyl acetate; $\alpha$-naphthyl acetate and propionate produce a background staining of the gel as does $\beta$-naphthyl 
laurate. The inhibition studies shown in FIGURE 1 were done using $\alpha$-naphthyl butyrate as substrate.

Naphthol AS acetate is hydrolyzed by bands 3,6 and 8; there is little hy-

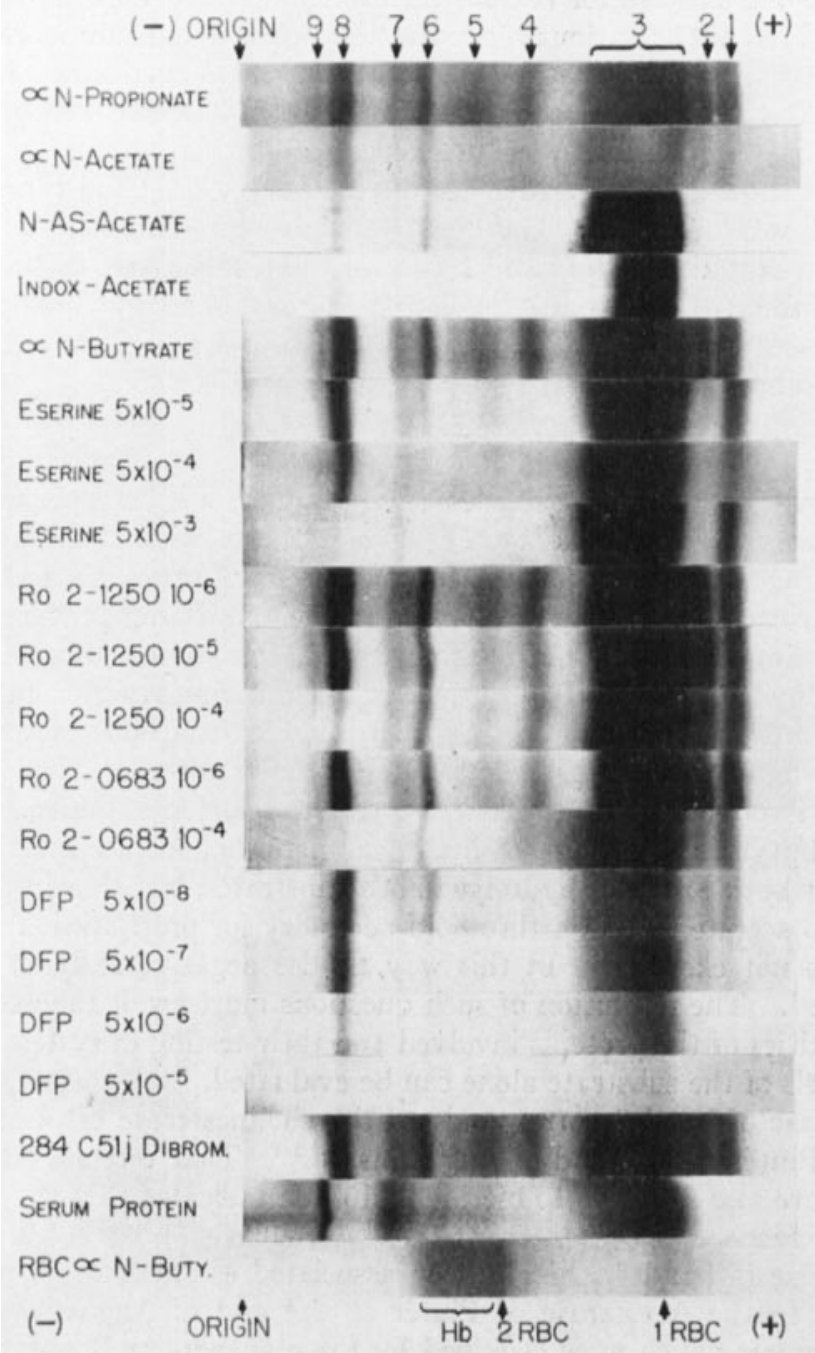

FIGURE 1.

drolysis by bands $2,4,5$, and 7 and no hydrolysis by bands 1 and 9 . Indoxyl acetate shows bands 3 and 8 and occasionally shows bands 4 and 6 . Only band 9 is demonstrated by $\beta$-naphthyl laurate plus sodium taurocholate; this band is difficult to see because of intense background staining and is not included in FIGURE 1. 
Eserine, in increasing concentrations, inhibits bands 2, 4, 5, 6, and 8 . The relation of the inhibition of each band to the concentration of the inhibitor can be noted on the figure. Eserine has some effect on band 9 and none on 1, 3, and 7. Ro 2-1250 inhibits band 8 as does Ro 2-0683. Band 5 does not show a consistent pattern for reasons mentioned above. DFP inhibits bands $1,2,4,5,6,7$, and 9 at various concentrations, some bands are more sensitive and others less sensitive. At the highest concentration even bands 3 and 8 are inhibited. At the concentrations used $\left(1 \times 10^{-6}, 1 \times 10^{-5}\right.$, and $1 \times 10^{-4}$ molar) $284 \mathrm{C} 51 \mathrm{j}$ dibromide is without effect.

The RBCs show 2 bands. In 2 instances a very weak band running faster than band 1 was observed. The hemoglobin is represented by a wide area (bracketed in FIGURE 1), and band 2 runs in the leading edge of this. Bands 1 and 2 are inhibited by $5 \times 10^{-5}$ molar eserine and band 2 is inhibited by the weakest concentration of DFP $\left(5 \times 10^{-7}\right)$. Bands 1 and 2 are not inhibited by $284 \mathrm{C} 51 \mathrm{j}$ dibromide.

\section{Discussion}

The observation that the esterase-active proteins of mouse plasma tend to hydrolyze the three short chain esters of $\alpha$-naphthol with equal facility, and the contrasting zymogram which is formed when naphthol AS acetate or indoxyl acetate are used as substrates is in agreement with our previous observations concerning mouse liver and kidney. ${ }^{11}$ At that time we concluded that the differences observed were due primarily to differing reaction rates on the part of enzymes in the column rather than to all or none substrate specificity. The results reported here provide no evidence for altering this conclusion, however, it is possible that the esterase of band 1, for example, hydrolyzes $\alpha$-naphthol butyrate and does not hydrolyze naphthol AS acetate. It is also possible that both esterases hydrolyze both substrates, but that in the case of naphthol AS acetate a certain threshold necessary for precipitation of the dye product was not exceeded. In this way a false negative reaction would be demonstrated. The resolution of such questions must await the extraction of larger quantities of the proteins involved and their testing in systems in which the hydrolysis of the substrate alone can be evaluated.

The esterase of band 8 corresponds to the cholinesterase of plasma, the $\mathrm{C}$ esterase of Pintér $e t a l .{ }^{18}$ and of Augustinsson. ${ }^{3,4}$ That esterases of bands 2, 4,5 , and 6 are also sensitive to eserine inhibition indicates that they may also be cholinesterases.

The esterase of band 3, the albumen associated esterase, in all probability corresponds to the A esterase of Pintér et al..$^{18}$ and of Augustinsson. ${ }^{3.4}$ To identify esterases which were classified by these authors as B esterases would be difficult, although bands 1,7 , and 9 would have to be considered. In addition, another unnumbered band can sometimes be identified located midway between bands 5 and 6 . This band may also be a group B or aliesterase.

The observation that the esterase of band 9 is the only enzyme demonstrated with $\beta$-naphthyl laurate and sodium taurocholate indicates that it is a lipase. An incidental observation is that this band can be well demonstrated if the columns are first incubated for one hour in acetone at $4^{\circ} \mathrm{C}$. before being treated with the substrate mixture. 
Perhaps our most interesting finding was in the different effects upon the esterases of mouse blood achieved by the five inhibitors used in this study. Other investigators ${ }^{1,7-10}$ have used these inhibitors to characterize the esterases in other species. On the basis of their results DFP, Ro 2-0683 and eserine all are effective inhibitors against cholinesterase with DFP inhibiting aliesterase as well. The inhibitors Ro $2-1250$ and $284 \mathrm{C} 51 \mathrm{j}$ are more effective against acetyl cholinesterase although higher concentrations $\left(10^{-5} M\right)$ of Ro 2-1250 also inhibit nonspecific or pseudocholinesterase. We are particularly impressed by the selective manner in which Ro 2-0683 and Ro 2-1250 inhibit the esterase of band 8 in contrast to the multiple band inhibition of eserine. All three inhibitors clearly inhibit the principle cholinesterase of plasma, but eserine inhibits other "cholinesterases" as well. We interpret the failure of $284 \mathrm{C} 51 \mathrm{j}$ to inhibit any of the bands to mean that acetylcholinesterase is not demonstrated by these methods. The total and unselective manner in which DFP inhibits the esterases of mouse plasma indicates that this inhibitor would be unsuited for characterizing these esterases other than that at higher concentrations it inhibits them all.

In any consideration of the esterases in plasma or serum the question of the relationship of these esterase-active proteins to the proteins in pherograms stained with amido black always arises. A comparison of the serum pherogram with the zymograms in the figure reveals that bands 3,5 , and 9 most nearly coincide with the proteins stained in the pherogram. Bands 1 and 2 would similarly coincide with pre-albumens but these proteins, although present in mouse serum, are not illustrated in FIGURE 1. The albumen-associated esterase (band 3) has been shown not to coincide in location with albumen when the proteins of mouse serum are separated by two-dimensional electrophoresis in the manner described by Smithies and Poulik. ${ }^{19}$ Whether the other esterases that seem to coincide with stainable proteins in the one dimensional zymogram would coincide if more refined methods of separation were used remains to be determined. In any event the two most prominent esterases of the zymogram, bands 3 and 8, are not simply being carried along by more abundant protein, and it is probable that most of the other esterases separated in starch-gel arrive at their location in the zymogram unattached to other proteins. The most likely counter example to this generalization is found in band 9 , which closely approximates the slow alpha two $\left(\mathrm{S} \alpha_{2}\right)$ globulin fraction in location and in band width.

It has been suggested that the multiple bands seen in the zymogram are due to a breaking up of a lesser number of esterases during the electrophoretic procedure. To test this hypothesis the following experiment was performed. The starch-gel column was set up in the usual way but was allowed to run for only 2 hours. Bands 3 and 8 were located using a thin slab sliced from the surface of the column to insert in the substrate mixture. The remaining larger portion of these bands was then sliced from the column and inserted in a second column at the origin. These were then run in the usual way. The resulting zymogram showed only two well-separated esterase bands, corresponding to bands 3 and 8 . From this we conclude that these intensely reactive bands are not contributing to the formation of the weaker bands by their own breakdown. 
With respect to the two esterases obtained from washed $\mathrm{RBCs}$, the fact that no inhibition was observed when $284 \mathrm{C} 51 \mathrm{j}$ or Ro $2-1250$ were used as inhibitors together with our failure to demonstrate an intensely reactive esterase in this material supposedly high in acetylcholinesterase activity, argues further against the conclusion that the esterases herein demonstrated are acetylcholinesterases. $\mathrm{RBC}$ esterase band 2, running in the leading edge of the hemoglobin, sensitive to eserine and DFP and better demonstrated when $\alpha$-naphthyl butyrate is used as substrate than when $\alpha$-naphthyl acetate is used, has a corresponding enzyme in man and in the rat.

Considering the many substances that have been used to study and characterize the esterases and the relatively small sample of these materials we have used in this investigation, it is interesting that such diversity of reaction has been observed. We conclude that it is unlikely that the esterases of mouse blood can be subdivided into groups sharing properties which would warrant their classification into isozymes.

\section{Summary and Conclusions}

The blood of mice has been analyzed for esterases using the zymogram method; 9 esterases in plasma and 2 in red blood corpuscles have been demonstrated. The effect of 6 substrates, 1 activator and 5 inhibitors upon these esterases has been determined. The results indicate that the multiple esterases present in mouse blood are not readily classifiable into subgroups containing common properties.

\section{Acknowledgment}

The technical assistance of Gordon R. Patton is gratefully acknowledged.

\section{References}

1. Alten, J. M., O. ERÄNKö \& R. L. Hunter. 1958. A histochemical study of the esterases of the adrenal medulla of the rat. Am. J. Anat. 102: 93-116.

2. AlleN, S. L. 1960. Inherited variations in the esterases of Tetrahymena. Genetics. 45: $1051-1070$.

3. AUGUSTINsson, K. B. 1958. Electrophoretic separation and classification of blood plasma esterases. Nature. 181: 1786-1789.

4. Augustinsson, K. B. 1959. Electrophoresis studies on blood plasma esterases. I. Mammalian plasmata. Acta Chem. Scand. 13: 571-592.

5. DEGrouchy, J. 1958. Répartition des activités estérasiques et phosphatasiques du sérum humain par rapport aux séro-protéines actuellement connues. Rev. Fr. clin. biol. 3: 881-884.

6. Dubbs, C. A., C. Vivonia \& J. M. Hilburn. 1960. Subfractionation of human serum enzymes. Science. 191: 1529-1530.

7. GouTiER, R. 1956. Etude électrophorétique des estérases sériques et de la fixation du $D^{32} \mathrm{P}$ dans le sérum, chez le lapin et le cobaye. Biochim. Biophys. Acta. 19: 524-534.

8. Hawkins, R. D. \& J. M. Gunter. 1946. Studies on Cholinesterases 5. The selective inhibition of pseudocholinesterase in vivo. Biochem. J. 40: 192-197.

9. Hawkins, R. D. \& B. MENDEL. 1949. Studies on Cholinesterase 6. The selective inhibition of true cholinesterase in vivo. Biochem. J. 44: 260-264.

10. Holmstedr, B. 1957. A modification of the thiocholine method for the determination of cholinesterase. 1. Biochemical evaluation of selective inhibitors. Acta Physiol. Scand. 40: 322-330.

11. Hunter, R. L. \& M. S. Burstone. 1960. The zymogram as a tool for the characterization of enzyme substrate specificity. J. Histochem. Cytochem. 8: 58-62.

12. Hunter, R. L. \& C. L. MarkerT. 1957. Histochemical demonstration of enzymes separated by zone electrophoresis in starch gels. Science. 125: 1294-1295.

13. Hunter, R. L., J. M. Denuce \& D. S. Strachan. Serum esterases in mice, rats and 
man using the two-dimensional zymogram method. 1st Intern. Congr. Histochem. Cytochem. In press.

14. Lawrence, S. H., P. J. Melnick \& H. E. Weimer. 1960. A species comparison of serum proteins and enzymes by starch gel electrophoresis. Proc. Soc. Exptl. Biol. Med. 105: 572-575.

15. Markert, C. L. \& R. L. Hunrer. 1959. The distribution of esterases in mouse tissue. J. Histochem. Cytochem. 7: 42-49.

16. Markert, C. L. \& F. Mørler. 1959. Multiple forms of enzymes: Tissue, ontogenetic, and species specific patterns. Proc. Natl. Acad. Sci. 46: 753-763.

17. Pintér, I. 1957. Esterase activity of serum protein fractions. Acta Physiol. Hung. 11: 39-44.

18. Pintér, I., G. Sávay \& B. A. Csillik. 1954. Szüröpapírelektroforézis útján szétválasztott fehérjefrakciók enzymaktivitásának kimutátása. Kisérl. Orvostud. 6: 513515.

19. Smithies, O. \& M. D. Poulik. 1956. Two-dimensional electrophoresis of serum proteins. Nature. 177: 1033. 